\title{
The Bloomsbury Companion to Berkeley, pod red. Richarda Brooka i Bertila Belfrage, Wyd. Bloomsbury, Londyn-Nowy Jork 2017, ss. I-IX, 1-525
}

DOI: http://dx.doi.org/10.12775/RF.2017.031

The Bloomsbury Companion to Berkeley to najnowsza anglojęzyczna monografia poświęcona filozofii Berkeleya, która w 2017 roku ukazała się nakładem wydawnictwa Bloomsbury. Stanowi ona najnowsze opracowanie poświęcone brytyjskiej filozofii w serii nowych kompendiów wiedzy obok prac dotyczących myśli Lockéa (2014), a także Hobbesa i Hume’a (2015). Do tej pory z publikacji podobnych kompendiów wiedzy słynęło przede wszystkim wydawnictwo Cambridge University Press, w którego serii monografia traktująca o filozofii Berkeleya ukazała się w 2005 roku pod redakcją Kennetha P. Winklera. The Bloomsbury Companion to Berkeley stanowi rezultat dalszych badań nad myślą brytyjskiego filozofa i dowodzi nie tylko wzmocnienia wcześniejszych, ale także pojawienia się nowych hipotez interpretacyjnych. Te ostatnie stały się możliwe w związku ze zwrotem komentatorów filozofii Berkeleya do manuskryptów jego dzieł, do czego zachęca pracujący nad ich nowym wydaniem krytycznym Bertil Belfrage, współredaktor wraz z Richardem Brookiem omawianego kompendium. Owo nowe podejście wiąże się także z próbą przywrócenia należytej uwagi wszystkim pracom filozofa. Zdaniem redaktorów The Bloomsbury Companion to Berkeley od czasów krytycznego wydania dzieł Berkeleya pod redakcją A. A. Luce’a i T. E. Jessopa, którzy, pomijając błędy redakcyjne, dokonali ich niesłusznego wartościowania, czytelnicy byli bowiem narażani na pokusę interpretowania myśli brytyjskiego filozofa na podstawie prac, jakie za jego życia były raczej ignorowane. W założeniu The Bloomsbury Companion to Berkeley ma stanowić obiektywne omówienie bogatej filozofii Berkeleya. Redaktorzy Belfrage i Brook podkreślaja, że ich wyłącznym celem jest „omówienie wszystkich dzieła Berkeleya, które to traktują o szerokim spektrum problemów: od filozofii naturalnej do psychologii, od teologii do ekonomii politycznej i polityki monetarnej, od filozofii moralnej do fizjologii i medycyny" (s. 1-2). 
Obiektywność i nowatorskość monografii wydawnictwa Bloomsbury w stosunku do kompendium Cambridge University Press wynika w pierwszej kolejności z całkowicie nowego, z wyjątkiem Patricka Kelly'ego, zespołu autorów. Co charakterystyczne dla serii Bloomsbury, Belfrage i Brook zaprosili do współpracy liczne, międzynarodowe grono wybitnych ekspertów, wśród których są także laureaci prestiżowego konkursu na najlepszy esej poświęcony filozofii Berkeleya, organizowany co roku przez amerykański Uniwersytet w Rochester (Colin and Ailsa Turbayne International Berkeley Essay Prize Competition). W odróżnieniu od wcześniejszego The Cambridge Companion to Berkeley autorami nowych opracowań są nie tylko naukowcy z krajów anglojęzycznych (tj. Stanów Zjednoczonych Ameryki [Talia Bettcher, Seth Bordner, Richard Brook, Laurence Carlin, James van Cleve, Charles McCracken, Georges Dicker, Keota Fields, Marc Hight, Nancy Kendrick, Jeff McDonough, Kenneth Pearce, Samuel Rickless, John Roberts, Howard Robinson], Wielkiej Brytanii [Tom Jones, Tom Stoneham] i Irlandii [Patrick Kelly] oraz Kanady [Sébastien Charles]). Artykuły znajdujące się w The Bloomsbury Companion to Berkeley przygotowali także czołowi badacze filozofii Berkeleya z Finlandii (Timo Airaksinen), Niemiec (Wolfgang Breidert), Szwajcarii (Richard Glauser), Szwecji (Bertil Belfrage), a także z Polski (Adam Grzeliński), co stanowi chwalebny wyjątek w porównaniu $\mathrm{z}$ pomijającymi polski wkład $\mathrm{w}$ aktualne badania nad filozofią nowożytną opracowaniami myśli Locke'a, Hobbesa czy Hume'a, jakie dotychczas ukazały się w serii wydawnictwa.

Swoje zamierzenia bezstronności redaktorzy monografii Bloomsbury realizują nie tylko poprzez dobór autorów artykułów, ale też poprzez interesujący układ treści. Artykuły krytyczne zostały uporządkowane w czterech równorzędnych częściach. Pierwsza z nich została poświęcona omówieniu biografii Berkeleya i znaczeniu jego filozofii. Rozpoczyna ją zaprezentowane przez Toma Jonesa nowe spojrzenie na życie Berkeleya jako podporządkowane celom w postaci praktykowania cnoty i czynienia dobra $\mathrm{w}$ wymiarze duchowym, moralnym i społecznym przy uwzględnieniu tak doczesnego, jak i wiecznego wymiaru ludzkiej egzystencji. Jones zwraca uwagę na rolę edukacji w realizacji życiowych zamierzeń Berkeleya. Uwidoczniły się one nie tylko w projekcie bermudzkim filozofa, ale były także obecne w jego zmaganiach $\mathrm{z}$ biedą w Irlandii, co spotkało się z uznaniem, jakie wyraził wobec niego katolicki myśliciel Charles O'Conor (1710-1791). Interesującego omówienia wątku edukacji w życiu i działalności, ale w kontekście projektu bermudzkiego Berkeleya dokonuje także w kolejnym artykule Nancy Kendrick. Inaczej niż większość komentatorów, którzy skupiają się na kwestii utopijności projektu, Kendrick wskazuje na jego rewolucyjność. Zdaniem autorki wiązała się ona z traktowaniem jednostki bardziej jako podmiotu praw moralnych, a nie politycznych i polegała $\mathrm{w}$ tym uję- 
ciu na postulowanej przez Berkeleya odpowiedzialności Brytyjczyków nie tylko za przywiedzenie Indian (choć już nie czarnoskórych niewolników) do wiary chrześcijańskiej, ale przede wszystkim za ich rozwój intelektualny. $\mathrm{W}$ ten sposób miało nastąpić ich uwolnienie $\mathrm{z}$ ciemności niewiedzy, a także obudzenie wśród nich ducha wspólnoty, jakkolwiek nie oznaczało ich wyzwolenia spod władzy brytyjskiej czy ich równouprawnienia. W opinii Kendrick skupienie na rozwoju intelektualnym rdzennych Amerykanów, nie zaś na bogaceniu się Imperium Brytyjskiego jako motywacji do obecności Brytyjczyków w Nowym Świecie zaważyło na niepowodzeniu projektu Berkeleya. W podobnym tonie, jeżeli idzie o brak wpływu postulatów zawartych $\mathrm{w}$ dziele Pytający, wypowiada się w drugiej części kompendium Patrick Kelly, omawiając w kontekście owego traktatu rolę Berkeleya $\mathrm{w}$ ruchu na rzecz poprawy sytuacji w Irlandii. Kluczem w zrozumieniu prosperity narodu dla Berkeleya nie była, jak zwraca uwagę Kelly, mająca podstawowe znaczenie dla ówczesnych merkantylistów ilość srebra czy złota w państwie, a posiadanie przez ludzi żywności, odzienia i schronienia, co stanowiło wynik podążania za dobrze rozumianymi potrzebami i celami egzystencji. Bogacenie się bowiem szło $\mathrm{w}$ parze $\mathrm{z}$ doskonaleniem się moralnym i nie oznaczało dla Berkeleya gromadzenia dóbr ponad miarę. Postulowany przez niego pieniądz papierowy miał być wyłącznie biletem, tj. środkiem płatniczym, który jako taki, sam w sobie, nie posiadał wartości. Co ważne, zdaniem Kelly'ego w ujęciu Berkeleya bogacenie się Irlandczyków nie miało powodować zmiany ich statusu społecznego. Ich zaradność i pracowitość, prowadzące do polepszenia losu poprzez handel krajowy bardziej niż zagraniczny, który filozof uważał za niekonieczny dla Irlandii, miały bowiem służyć rozwojowi gospodarki brytyjskiej. Trzeci artykuł pierwszej części kompendium stanowi dokonane przez Marca Highta krytyczne wprowadzenie do korespondencji Berkeleya, którą autor opublikował w 2012 roku. Prócz informacji o źródłach oraz zarysu zawartej w niej problematyki, Hight przedstawia głównych korespondentów Berkeleya (tj. Johna Percivala, Thomasa Priora, Samuela Johnsona, Henry'ego Newmana, Martina Bensona i Isaaca Gervaisa). Część pierwszą monografii zamyka interesujące omówienie przez Howarda Robinsona aktualności rozważań Berkeleya w kontekście sporu o realizm w XX-wiecznej filozofii brytyjskiej, w tym w szczególności wpływu filozofa na koncepcje antyrealizmu semantycznego Michaela Dummetta (zm. 2011) i idealizmu fenomenalistycznego Johna Fostera (zm. 2009). Do poruszanej przez Robinsona Popperowskiej próby odczytania Berkeleya jako prekursora Macha i Einsteina nawiązuje także Richard Brook przy okazji omówienia $\mathrm{w}$ drugiej części kompendium zagadnienia filozofii nauki Berkeleya w kontekście analizy dzieła De Motu ze szczególnym uwzględnieniem zawartych w nim rozważań nad fenomenem siły oraz naturą przestrzeni i ruchu z punktu widzenia filozofii naturalnej. 
Artykuły w kolejnych trzech częściach kompendium mają bardziej polemiczny charakter. W części drugiej, która została poświęcona „ważniejszym dziełom" Berkeleya, prócz informacji odnotowujących okoliczności czasu i miejsca ich powstania, zostały zaprezentowane nowe interpretacje zawartych w nich wybranych problemów. Serię omówień rozpoczyna artykuł poświęcony Teorii widzenia autorstwa Bertila Belfrage. Zawiera on polemikę z traktowaniem teorii widzenia Berkeleya jako próby metafizycznej obrony idealizmu, który to pogląd zdaniem Belfrage prezentuje Margaret Atherton. Autor proponuje rozważanie Berkeleyowskich analiz fenomenu widzenia z perspektywy atomistycznej psychologii, której charakterystykę podaje w odniesieniu do czasów powstawania nowej teorii widzenia. W kolejnym artykule Samuel Rickless, przedstawiając problematykę Traktatu o zasadach poznania ludzkiego, oprócz krytycznej prezentacji treści dzieła proponuje m.in. nową interpretację rozumowania mistrza (The Master Argument). Perspektywę prezentacji Trzech dialogów, jakiej dokonuje dalej Tom Stoneham, wyznacza zagadnienie sceptycyzmu oraz polemika z jego charakterystyką dokonaną przez Richarda Popkina. Według Stonehama źródeł Berkeleyowskiej wizji postawy sceptycznej, jaka ujawnia się w rozmowie Hylasa z Filonusem, można upatrywać nie tylko u Pierre'a Bayle'a, jak czyni to Popkin, ale także u Michela du Montaigne'a czy Thomasa Stanleya, nie mówiąc już o wpływie myśli Sekstusa Empiryka czy Diogenesa Laertiosa, którego Żywoty i poglady stawnych filozofów wyznaczały nowożytne myślenie o owym zjawisku.

Co niezwykle ważne, do zbioru „ważniejszych” dzieł redaktorzy Belfrage i Brook zaliczają także prace związane bardziej z filozofią praktyczną Berkeleya, które dotąd pozostawały w cieniu Traktatu czy Nowej teorii widzenia. W tym względzie ciekawym wkładem w dyskusję nad myślą moralną Berkeleya jest prezentacja treści trzech kazań Berkeleya pt. Bierne postuszeństwo, której dokonuje Belfrage. Dzięki odkryciu wyciagu z tej pracy, jaki powstał na ich bazie w 1730 roku, Belfrage w uzasadniony sposób może skoncentrować się na zagadnieniu dobra moralnego i fundamentalizmie proponowanym przez filozofa, aniżeli na rodzącej wśród komentatorów kontrowersje kwestii posłuszeństwa wobec władcy, które prowadzi do sprzeczności z postulowanym przez filozofa obiektywizmem etycznym. Zwracając uwagę na doktrynę teologicznego pozytywizmu i podziału na obszary rzeczy dostępnych i niedostępnych poznaniu ludzkiemu, Belfrage dokonuje charakterystyki wczesnego podejścia Berkeleya do zagadnień moralnych oraz jego postulatów w określeniu właściwej relacji między Bogiem a człowiekiem oraz osiągnięciem przez niego życia wiecznego.

Trzy ostatnie artykuły w części drugiej dotyczą bardziej obszernych z mniej znanych dotąd dzieł Berkeleya, tj. dialogów Alkifron, Pytającego oraz Siris. W opinii autorów zyskują one miano prac przełomowych, 
co stanowi novum w kontekście marginalnej roli, jaką do tej pory im przypisywano. Prócz rekonstrukcji Berkeleyowskiej krytyki wolnomyślicielstwa w odniesieniu do poszczególnych dialogów Alkifron Adam Grzeliński podejmuje za Davidem Bermanem polemikę z przekonaniem Luce'a i Jessopa, że Berkeley nie przedstawił w nim własnych poglądów. Polski badacz wskazuje między innymi na możliwość odnalezienia w Alkifronie powtórzeń tez zawartych w Traktacie o bierności idei i czynności umysłów, czy rozróżnienia filozofii naturalnej od metafizyki zasugerowanego już w De Motu, jak również argumentów na rzecz powolnej rezygnacji z religijnego radykalizmu głoszonego przez Berkeleya w latach 1712-1721. Sugeruje jednak, że stanowi to początek w procesie budowania neoplatońskiej metafizyki przedstawionej w pełnym wymiarze w Siris. Zdaniem Timo Airaksinena, który poświęca owemu dziełu kolejny artykuł, znajomość jego treści jest konieczna, by zrozumieć Berkeleya jako filozofa i naukowca, tym bardziej, że dochodzą w nim do głosu zupełnie nowe motywy filozoficzne, nieobecne $\mathrm{w}$ dziełach wcześniejszych. Odkrywając w polemice z Davidem Bermanem sekrety Siris, w tym monizm Berkeleya, Airaksinen podkreśla, że do tej pory traktat niesłusznie dyskredytowano ze względu na przewodni w nim temat wody dziegciowej. Zdaniem fińskiego badacza nie można zapomnieć, że dzieło zawiera bowiem fascynujące rozważania nad relacją nauki i religii, zdrowiem i życiem, które zdradzają Berkeleyowskie nowe koncepcje idei abstrakcyjnych, teorii przyczynowości czy definicji wolności człowieka.

Trzecia część kompendium ukazuje wybrane wątki filozofii Berkeleya w relacji do poglądów innych współczesnych mu myślicieli anglo-, niemiecko- i francuskojęzycznych. Perspektywa porównań została tu zawężona do problematyki z obszaru filozofii bytu i poznania. W przypadku myślicieli brytyjskich poglądy Berkeleya zestawiono z koncepcjami Locke'a, Reida i Hume'a. Dokonywane przez Georgesa Dickera zestawienie filozofii Berkeleya i Locke'a dotyczy ich teorii percepcji. Z jednej strony Dicker zwraca uwagę na możliwość obrony teorii Locke’a przed jej krytyką ze strony Berkeleya (Locke bowiem przyznaje, że postrzegamy nie tylko idee, ale i rzeczy materialne), z drugiej - wskazuje, pod jakimi względami Berkeleyowska argumentacja była zasadna. To ostatnie jest możliwie w kontekście szczegółowego omówienia postrzegania bezpośredniego w koncepcji Berkeleya, w czasie którego Dicker, polemizując z Samuelem Ricklessem, wyróżnia trzy możliwości rozumienia owego fenomenu. $Z$ kolei w zestawieniu Berkeleya $\mathrm{z}$ Reidem, James van Cleve wskazuje na różnice i podobieństwa wizji obu filozofów pod kątem zawartych $\mathrm{w}$ nich teorii idei oraz poglądów na naturę przestrzeni i postrzegania wzrokowego, podejmuje także próbę oceny tych ostatnich pod względem ich adekwatności. Motywem przewodnim omówienia wpływu filozofii Berkeleya na koncepcję Hume'a, jakiego dokonuje 
w kolejnym artykule Keota Fields, jest zagadnienie wyobraźni i powstawania reprezentacji w umyśle.

Relacje myśli Berkeleya i przedstawicieli filozofii niemieckiej w XVII wieku zostały zawężone do ich zestawienia poglądów brytyjskiego filozofa z przekonaniami Leibniza. Autor artykułu Laurence Carlin dowodzi, że choć obaj filozofowie byli wobec siebie krytyczni, obaj argumentowali także na rzecz fenomenalizmu. Badacz przygląda się szczegółowo poglądom Berkeleya i Leibniza na naturę siły i nieskończonej podzielności, by pokazać, jak doprowadziły one do różnych koncepcji przyczynowości i wyjaśnień naukowych, a w konsekwencji do odmiennych wizji szczęścia ludzkiego. Twierdzi on przy tym, że problematyka filozofii Berkeleya i Leibniza pozostaje podobna pod względem przenikania się $\mathrm{w}$ nich kwestii teologicznych, etycznych, naukowych i filozoficznych.

Nieco szerzej jest analizowana zależność między Berkeleyem a francuską filozofią nowożytną. Charles McCracken wskazuje na wpływ koncepcji Kartezjusza na przekonanie Berkeleya o istnieniu świata zewnętrznego oraz na jego filozofię umysłu. Przy okazji omówienia relacji myśli Berkeleya i Malebranche'a w kolejnym artykule skupia się z kolei na problemie istnienia oraz natury materii i umysłu, kwestii widzenia rzeczy w Bogu i okazjonalizmu. Oryginalnym wkładem w przedstawienie recepcji Berkeleya w XVIII-wiecznej Francji jest artykuł Sébastiena Charlesa, traktujący o poglądach nowożytnych myślicieli francuskich z kręgów jezuickich oraz encyklopedystów. Charles dowodzi, że niemal wszyscy doszukiwali się w filozofii Berkeleya solipsyzmu, który zgodnie krytykowali, choć bez podawania argumentów. Ewentualni zwolennicy Berkeleya ujawniali się przy okazji krytyki filozofów oświeceniowych. Jako przykład myśliciela, który przedstawił najbardziej oryginalną próbę apologii immaterializmu Berkeleya Charles wskazuje Nicolasa-Sylvestre’a Bergier'a (1718-1790), autora hasła „Ciało" w Słowniku filozoficznym (1764) Voltaire'a.

W części czwartej The Bloomsbury Companion to Berkeley zostały przedstawione krytyczne analizy wybranych zagadnień filozofii Berkeleya. Z wyjątkiem artykułów poświęconych poglądom Berkeleya z zakresu filozofii matematyki (Wolfgang Breidert) oraz filozofii religii, który uwzględnia problematykę religii naturalnej i objawionej (Kenneth Pearce), dotyczą one, podobnie jak w poprzedniej części, filozofii bytu i poznania. Seth Bordner skupia się na wyjaśnieniu znaczenia zdroworozsądkowości poglądów Berkeleya, którą postulował sam filozof, a także przypisywali mu komentatorzy jego myśli. Interesującym wkładem w te rozważania jest artykuł Jeffa McDonougha, podejmujący próbę odpowiedzi na pytanie, w jaki sposób metafizyczne stanowisko Berkeleya pozwala skonceptualizować istnienie zwykłych przedmiotów, takich jak stoły, krzesła, koty czy psy. W następnym artykule Talia Mae Bettcher 
zwraca uwagę na Berkeleyowską koncepcję umysłu i podejmuje próbę interpretacji dzieł filozofa pod kątem relacji podtrzymywania $\mathrm{w}$ istnieniu, jaka łączy rzeczy i umysły oraz działań samego umysłu oraz ich stosunku wobec aktów woli. Swoje analizy autorka uzupełnia prezentacją rozwoju Berkeleyowskiej koncepcji umysłu aż do trzeciego wydania Dialogów w 1734 roku. John Russel Roberts z kolei omawia Berkeleyowskie zainteresowanie językiem i interpretuje poglądy filozofa na temat znaczenia w kontekście teorii ideowej znaczenia i teorii użycia, wskazując tę drugą jako spójną z metafizyką substancji duchowych Berkeleya.

Mogłoby się wydawać, że trudno uzasadnić powstanie The Bloomsbury Companion to Berkeley w tak krótkim ostatecznie czasie po publikacji The Cambridge Companion to Berkeley. Dzielące obie monografie dwanaście lat było wypełnione jednak dalszymi badaniami nad filozofią Berkeleya i, co więcej, nowymi odkryciami. Jak dowodzą autorzy artykułów kompendium wydawnictwa Bloomsbury, nowatorskie spojrzenie na problemy poruszane przez Berkeleya jest możliwe, nadal bowiem są one pasjonujące dla badaczy. Prócz obiektywności analiz prezentowanych $\mathrm{w}$ artykułach kompendium ogromną zaletą jest niewątpliwie ich polemiczny charakter. Autorzy bowiem, bez wyjątku, wchodzą w dyskusję z interpretacjami, które do tej pory mogły uchodzić na wzorcowe (por. np. Atherton, Bennett, Berman, Pitcher). Za znak czasu można potraktować w tym wglądzie także nieobecność w gronie autorów Davida Bermana, niekwestionowanego autorytetu dla współczesnych badaczy filozofii Berkeleya. Przy okazji omówienia biografii myśliciela zastąpił go tym razem Tom Jones, pracujący nad nową monografią poświęconą jego życiu i dziełu, Berman zaś był autorem jednej z wydawniczych recenzji tomu, co pozwala mówić o dokonującej się zmianie pokoleniowej $\mathrm{w}$ badaniach nad Berkeleyem.

The Bloomsbury Companion to Berkeley jest przeznaczony dla każdego - zarówno osób, które chcą zaznajomić się z myślą i dziełem filozofa, na entuzjastach jego myśli kończąc. Zaproponowany przez redaktorów układ treści monografii zapewnia czytelnikowi intrygującą lekturę, którą można prowadzić na różne sposoby, tj. np. śledzić chronologiczny rozwój poglądów filozofa od Teorii widzenia do Siris, także w kontekście europejskich rozważań nowożytnych, albo skupić się na aktualnych dyskusjach badaczy nad problemami wynikającymi z Berkeleyowskiej metafizyki, epistemologii czy filozofii języka. W związku z tym, że są one omawiane pod różnym kątem, czytelnik może również bardziej szczegółowo zapoznać się z bogactwem aspektów intelektualnej wymiany zdań, jaka, jak widać, nadal pozostaje żywa wśród badaczy Berkeleya na świecie i dotyczy coraz szerszej problematyki, jaką uwzględnia myśl filozofa. Przypomnienie w tym kontekście tak ważnych dzieł Berkeleya jak Bierne posłuszeństwo, Pytajacy czy Siris, jakie do tej pory cieszyły się mniejszą uwagą badaczy, może okazać się dla czytelnika kompendium 
miłym zaskoczeniem. Podobnie, ucieszy go być może również uwzględnienie prezentacji Berkeleyowskich przemyśleń $\mathrm{w}$ dziedzinie filozofii praktycznej. O ile same tematy filozofii moralnej, filozofii religii czy rozważań ekonomicznych nie są nowe w kontekście wcześniejszych badań nad myślą Berkeleya (The Cambridge Companion to Berkeley także zawiera artykuły poświęcone tej tematyce), o tyle zaprezentowane interpretacje przełamują dotychczasowe stereotypy. Szkoda zatem, że nie udało się zgromadzić jeszcze więcej tekstów o podobnej tematyce. Jak sugerują na wstępie redaktorzy kompendium, to właśnie z mniej popularnych dziś wśród komentatorów dzieł filozof był bowiem znany za swego życia.

Czy dzięki The Bloomsbury Companion to Berkeley filozofia Berkeleya stała się już całkowicie znana? Jak się wydaje, na całe szczęście nie. Z pewnością dzięki nowej monografii z zapomnienia została wydobyta mniej popularna do tej pory myśl filozofa. Jednakże, jak na prawdziwych entuzjastów Berkeleya przystało, autorzy kompendium poważnie traktują jego zamierzenie pobudzania do myślenia. Stawiając w swych interpretacjach pytania, zachęcają czytelnika do sięgnięcia do samych dzieł filozofa i polemiki, co otwiera możliwość kolejnych interpretacji. Czy nie tak właśnie powinno wyglądać doskonałe kompendium?*

Marta Szymańska-Lewoszewska Uniwersytet Mikołaja Kopernika, Toruń e-mail: martaewa.szymanska@gmail.com

\footnotetext{
* Publikacja została sfinansowana ze środków Narodowego Centrum Nauki przyznanych w ramach finansowania stażu po uzyskaniu stopnia naukowego doktora na podstawie decyzji numer DEC-2014/12/S/HS1/00153.
} 